\title{
Does Big Mean Evil? Giant, but Benign Uterine Leiomyoma: Case Report and Review of the Literature
}

\section{Será que grande significa maligno? Leiomioma gigante, porém benigno: Relato de caso e revisão de literatura}

\author{
Luiz Gustavo Oliveira Brito ${ }^{1,2}$ () \\ Natalia Lysei Ueno ${ }^{2}$ \\ Department of Obstetrics and Gynecology, Faculdade de Ciências \\ Médicas da Universidade de Campinas, Campinas, SP, Brazil \\ 2 Department of Gynecology and Obstetrics, Faculdade de Medicina \\ de Ribeirão Preto da Universidade de São Paulo, Ribeirão Preto, SP, \\ Brazil
}

\author{
Maira Rossmann Machado ${ }^{10}$
}

\begin{abstract}
Address for correspondence Luiz Gustavo Oliveira Brito, MD, MsC, PhD, Rua Alexander Fleming, 101, Campinas, SP, 13083-881, Brazil (e-mail: Igobrito@unicamp.br).
\end{abstract}

Rev Bras Ginecol Obstet 2021;43(1):66-71

\begin{abstract}
Uterine leiomyoma is the most prevalent benign type of gynecological tumor. It affects more than $80 \%$ of women worldwide and, within this group, more than $50 \%$ may be asymptomatic. However, large fibroid volumes may be associated with symptoms of extrinsic compression, and most of the cases do not present atypical cells. We present the case of a 49-year-old woman who underwent a total abdominal hysterectomy of a

Keywords

- uterine leiomyoma

- giant tumors

- gynecological tumors $13.5-\mathrm{kg}$ uterine leiomyoma with no malignancies at histopathology and review the literature about giant uterine leiomyomas and their clinical repercussion. We concluded that large volumes do not always pose a threat regarding malignancy; however, future molecular studies are needed to investigate giant uterine fibroids.
Resumo
Leiomioma uterino é o tumor benigno ginecológico de maior prevalência. Ele afeta mais de $80 \%$ das mulheres no mundo e, deste grupo, mais de $50 \%$ podem ser assintomáticas. Contudo, miomas de grande volume podem ser associados com sintomas de compressão extrínseca, e a maioria dos casos não apresentam células atípicas. Nós apresentamos o caso de uma mulher de 49 anos que foi submetida a histerectomia total abdominal de um espécime de 13,5 quilos sem malignidades ao exame histopatológico. Também revisamos a literatura sobre leiomiomas uterinos de grande volume e sua repercussão clínica. Concluímos que grandes volumes nem sempre representam um risco relacionado à malignidade; contudo, estudos molecu- lares futuros são necessários para investigar leiomiomas uterinos gigantes.

received

May 25, 2020

accepted

September 22, 2020
DOI https://doi.org/

10.1055/s-0040-1721351. ISSN 0100-7203. (c) 2021. Federação Brasileira das Associações de Ginecologia e Obstetrícia. All rights reserved.

This is an open access article published by Thieme under the terms of the Creative Commons Attribution License, permitting unrestricted use, distribution, and reproduction so long as the original work is properly cited. (https://creativecommons.org/licenses/by/4.0/)

Thieme Revinter Publicações Ltda., Rua do Matoso 170, Rio de Janeiro, RJ, CEP 20270-135, Brazil 


\section{Introduction}

Uterine leiomyoma is a benign gynecological tumor originated from smooth muscle cells that affects up to $80 \%$ of women worldwide. From these, only 20 to $30 \%$ resent symptoms. ${ }^{1}$ Multiple risk factors are associated with leiomyoma development, with the most common ones being nulliparity, obesity, early menarche, African descent, and age, all of them secondary to an extended exposure to estrogens or genetic predisposition. ${ }^{1}$

Leiomyomas are classified as giant when their weight exceeds $11.4 \mathrm{~kg}^{2}$ They are included in the category of giant tumors, which is a concept that can also include ovarian tumors. Giant leiomyomas, in addition to the usually reported increase in abdominal size, presents other common clinical signs are mainly related to extrinsic compression. Examples of these signs and symptoms are worsening of the renal function, bowel obstruction, venous stasis, respiratory discomfort, thrombosis, and lymphedema. ${ }^{1}$ Most of the cases only cause severe symptoms after a long period of growth. Herein, we describe the case of a patient with a growing abdominopelvic mass, the pre and postoperative results, and the immediate postoperative surgical evolution. Moreover, we present a review of the literature. The inclusion criteria for this review were all case reports on patients over 18 years old with uterine weight over $10 \mathrm{~kg}$. We excluded all case reports with no data reporting weight and those whose authors did not answer about the weight of the specimen. The search strategy was composed of the following structure: ("uterine leiomyoma" OR "uterine fibroids" OR "uterine tumors") (large OR giant), and the search was performed on January $3^{\text {rd }}, 2020$ in the PubMed database with 577 results. Manuscript language was not considered a barrier for inclusion in this review. References were also consulted for analysis, as well as similar studies that were suggested in the PubMed website. Of these studies, 19 case reports that described giant leiomyomas were selected for analysis, and - Table 1 displays detailed data for 14 of them. ${ }^{2-20}$

\section{Case Report}

A 49-year-old nulliparous, obese woman with chronic hypertension sought medical care due to an increase in the size of her abdomen ( $\mathbf{- F i g . ~ 1 ) ~ f o r ~ o n e ~ y e a r . ~ S h e ~ w a s ~ a m e n o r r h e i c ~}$ for about a year without the use of contraceptives, and, 6 months prior to her consultation, she had been submitted to an abdominal computerized tomography (CT), which showed a uterine mass measuring $25.7 \times 29.0 \times 29.5 \mathrm{~cm}$ (volume 11,432.9 cc). The patient presented with complaints of frequent urination and urinary incontinence, with a urinary infection diagnosed on screening laboratory evaluation. Physical examination revealed a palpable abdominopelvic mass located up to $2 \mathrm{~cm}$ below the xiphoid process. Gynecological examination was unaltered, and no malignancy was found in the pap smear.

As there were no previous radiological exams evaluating the uterine growth rate and we could not rule out leiomyo- sarcoma for this patient preoperatively (a preoperative endometrial sample was attempted - Pipelle de Cormier) without sufficient material, a total abdominal hysterectomy with bilateral salpingo-oophorectomy was scheduled. One week before surgery, the patient underwent a magnetic resonance imaging (MRI), and the size of the tumor did not present any alterations. No hypothesis for leiomyosarcoma was performed. One day before the surgery, the patient was complaining of progressive abdominal pain, constipation, and urinary retention. Low-molecular weight heparin (enoxaparin) was administered prophylactically prior to surgery. A median incision was performed, and surgery (total hysterectomy plus prophylactic salpingectomy) occurred with no abnormalities, with an estimated blood loss of $600 \mathrm{ml}$, measured by compress weighing. An enormous uterine mass, weighing $13.5 \mathrm{~kg}$, was removed (-Fig. 2). Ureterolysis was performed to confirm that both ureters were intact.

Intraoperative histological analysis of the mass revealed no atypia, and the specimen was sent to pathology. No complications occurred in the immediate postoperative period, and the patient was discharged two days after the surgery. Gross macroscopy did not find any abnormalities, except for a giant uterine fibroid, with abundant vasculature in the periphery of the lesion. No areas of degeneration were seen. Histopathological examination evidenced leiomyoma with no atypia or degeneration and unaltered adnexa. The patient was discharged with no complications.

\section{Discussion}

Giant leiomyomata are rare, and not frequently reported in the literature. They are of special interest when presenting with a fast growth rate, which suggests malignancy, as uterine cancers usually present with signs and symptoms similar to benign tumors of the uterus and there are no specific criteria for the suspicion of leiomyosarcoma. ${ }^{1}$ The first report of these cases occurred in 1888, with the highest reported uterine tumor $(63.6 \mathrm{~kg})$, which was operated by Hunt et al. ${ }^{3}$ after an autopsy. Behrend ${ }^{4}$ operated a $60 \mathrm{~kg}$ tumor, and the patient died due to pneumonia 48 hours later. ${ }^{4}$ Singhabhandhu et al. $^{5}$ have described the largest uterine tumor removed with survival of the patient $(45.5 \mathrm{~kg}$ ).

A case series $(n=2)$ published by Oelsner et al. ${ }^{7}$ has performed a literature review, and 57 reported cases were found up to 2003. After 2003, our review has identified 13 cases plus the one described in the present article, thus comprising 71 cases. Our table summarizes most of the recent cases, and, after 2003, the largest reported uterine leiomyoma weighed $28.1 \mathrm{~kg} .{ }^{18}$ The main complaint is the progressive enlargement of the abdomen, and, in some cases, serious malnutrition was observed, as well as complications related to other organs that were damaged due to the expanding abdominopelvic tumor. One of the reported cases ${ }^{15}$ presented with a coexisting endometrial tumor, and only one case after the 2003 review evolved with death. ${ }^{19}$ 


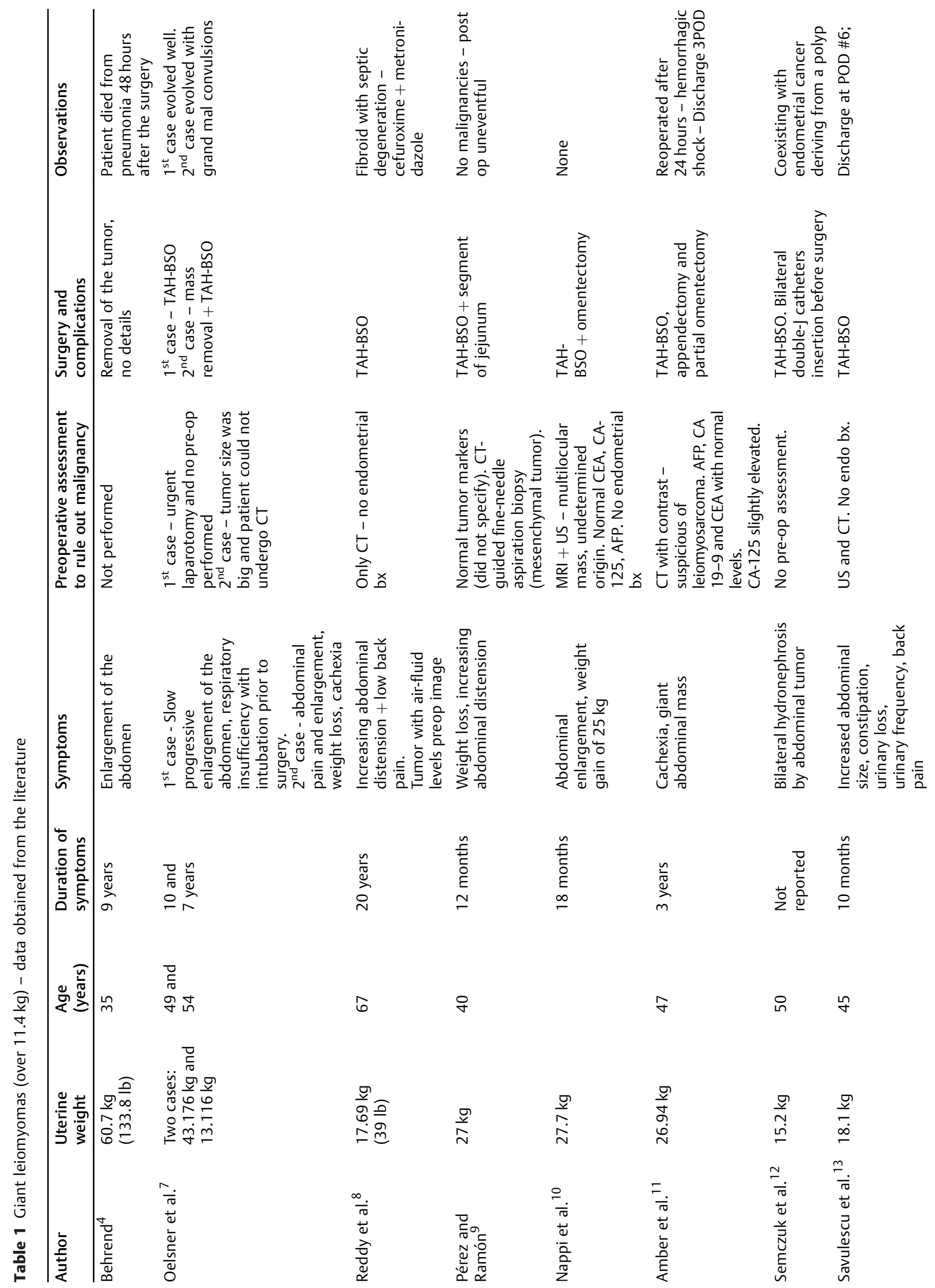


Does Big Mean Evil? Giant, but Benign Uterine Leiomyoma Brits et al.

69

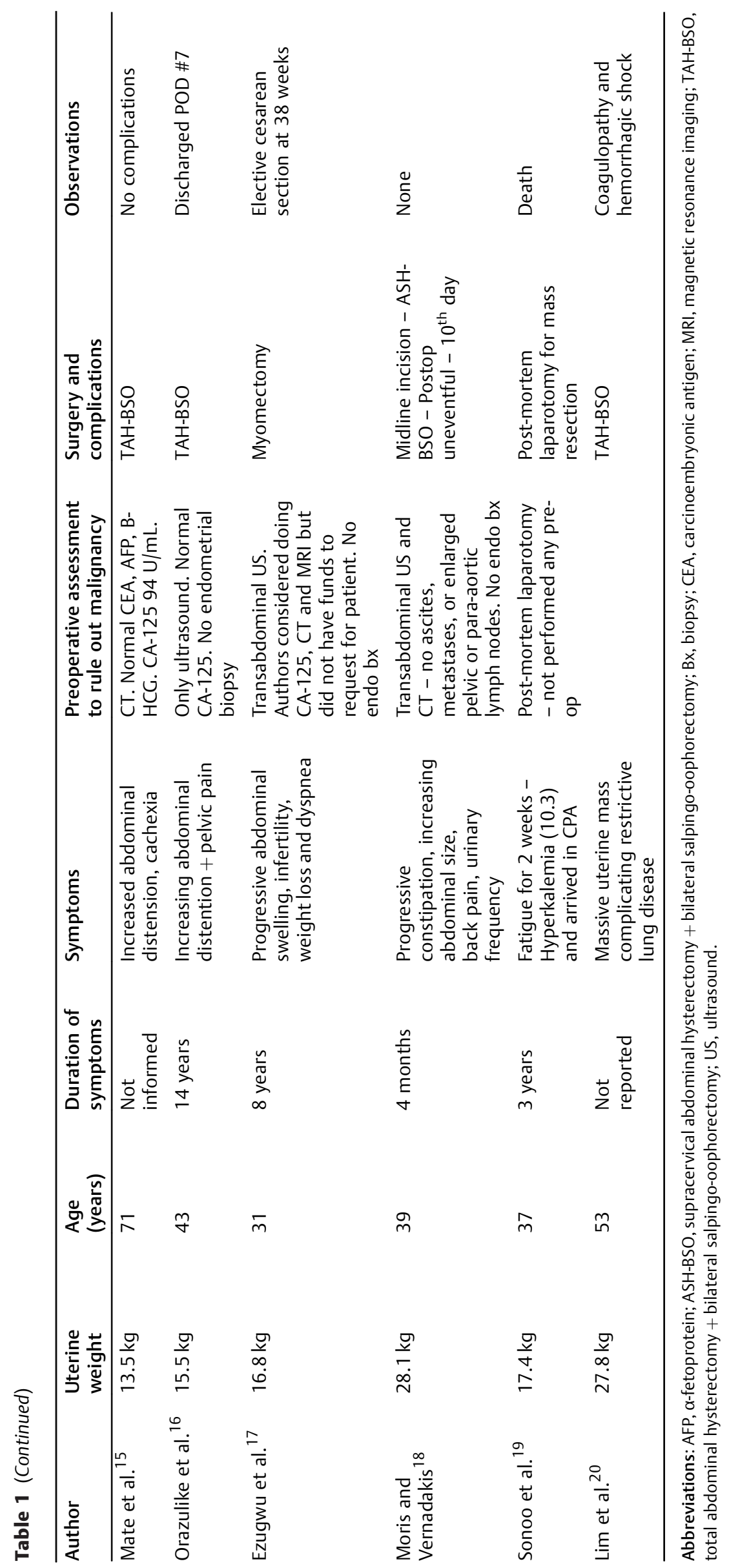

Rev Bras Ginecol Obstet Vol. 43 No. 1/2021 $\quad$ (c) 2021. The Author(s). 


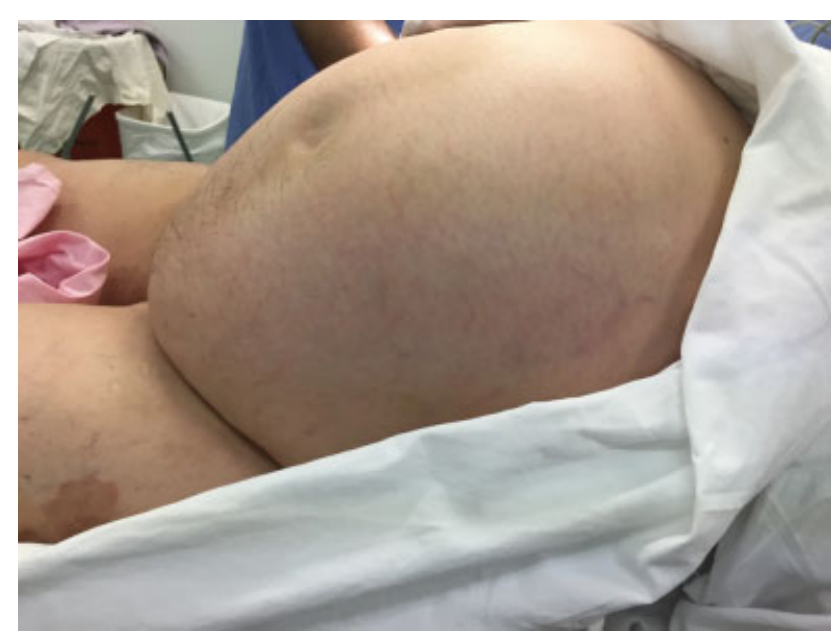

Fig. 1 Giant mass occupying all abdomen.

Surgery can be challenging in these cases. It is quite difficult to consider a minimally invasive approach in a large abdomen, as most of the incisions were xiphopubic. Within the selected cases, only one case was performed myomectomy-it was a nulliparous woman. ${ }^{17}$ As the uterine tumor presents large dimensions, the standard treatment for uterine sarcomas (total hysterectomy + bilateral salpingo-oophorectomy) is suggested and performed. A multidisciplinary approach with other specialties (general surgeon, plastic surgeon, urology) may be needed to help the gynecological surgeon during this procedure.

The present case report does not show an association between tumor size and malignancy. We need to understand the biological behavior of significantly enlarged leiomyomas with molecular approach. A study comparing large leiomyomas versus simple uterine leiomyomas has shown that there are large growth rates are present in fibroids from adolescent women. ${ }^{21}$ There is a systematic review studying uterine leiomyoma in adolescents, and the biological behavior of these tumors in women under 20 years seems to be different, because they present higher growth rates in adolescents than in adults. ${ }^{22}$ In summary, there is a need for further elucidation on the relationship between giant uterine fibroids and their growth rate and the associated malignancy potential.

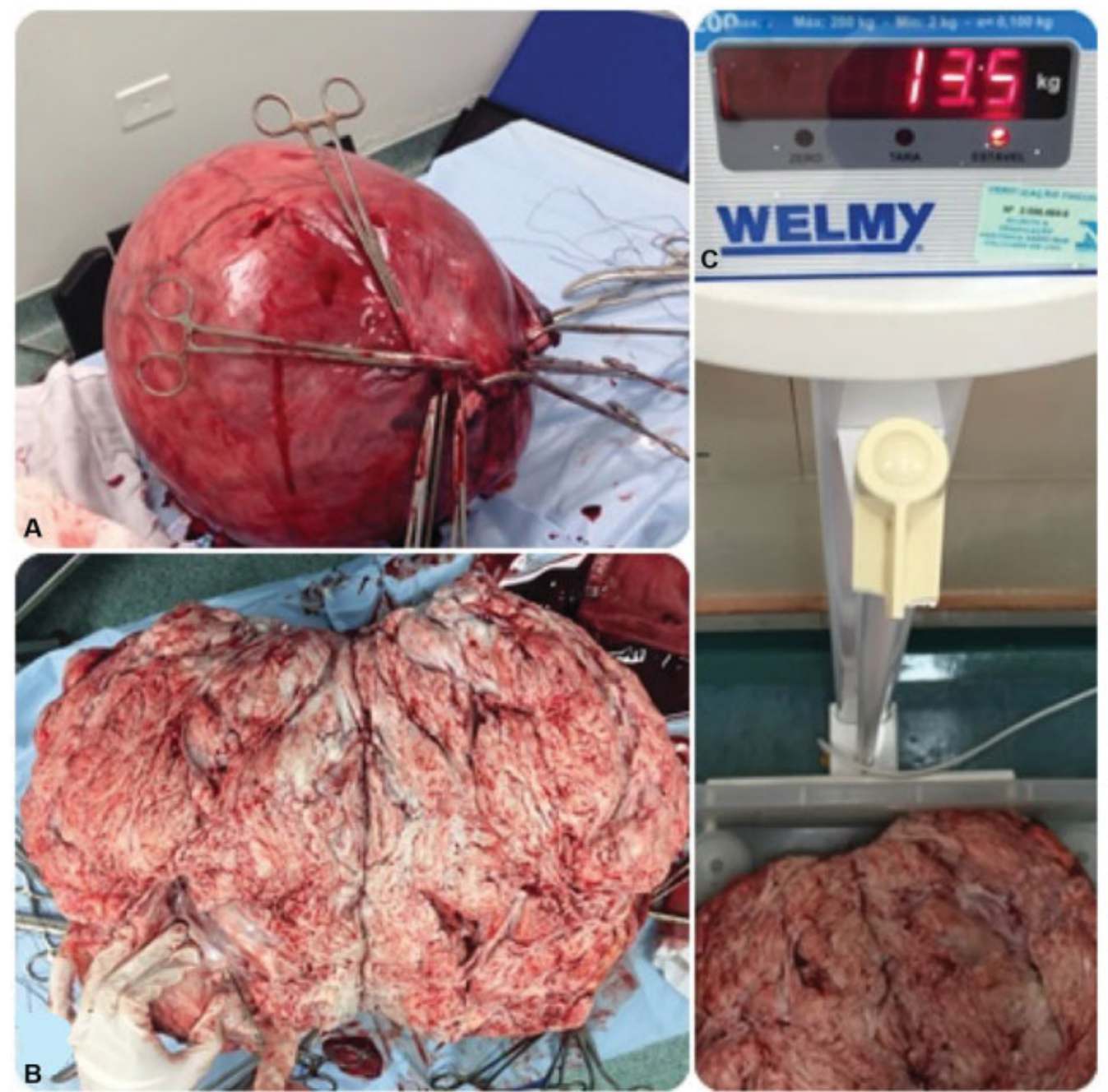

Fig. 2 (A) Voluminous uterus extracted after hysterectomy. (B) Macroscopic aspect of a leiomyoma (cut section). (C) Specimen weighing $13.5 \mathrm{~kg}$. 


\section{Conflict of Interests}

The authors have no conflict of interests to declare.

\section{Acknowledgments}

We acknowledge the patient that gave her written consent to have her case reported. This case report has been approved by the Institutional Review Board.

\section{References}

1 Moroni R, Vieira C, Ferriani R, Candido-Dos-Reis F, Brito L. Pharmacological treatment of uterine fibroids. Ann Med Health Sci Res. 2014;4(Suppl 3):S185-S192. Doi: 10.4103/2141-9248.141955

2 Jonas HS, Masterson BJ. Giant uterine tumors: case report and review of the literature. Obstet Gynecol. 1977;50(1, Suppl)2s-4s

3 Hunt SH. Fibroid weighing one hundred and forty pounds. Am J Obstet Dis Women Child. 1888;21(01):62-63

4 Behrend M. Report of a case of fibromyoma of the uterus weighing 133 pounds removed at operation. Am J Obstet Gynecol. 1930;20 (05):699-702. Doi: 10.1016/S0002-9378(30)90197-4

5 Singhabhandhu B, Akin JT Jr, Ridley JH, Gray SW, Skandalakis J. Giant leiomyoma of the uterus: report of a case and review of the literature. Am Surg. 1973;39(07):391-397

6 Evans AT III, Pratt JH. A giant fibroid uterus. Obstet Gynecol. 1979; 54(03):385-386

7 Oelsner G, Elizur SE, Frenkel Y, Carp H. Giant uterine tumors: two cases with different clinical presentations. Obstet Gynecol. 2003; 101(5 Pt 2):1088-1091. Doi: 10.1016/s0029-7844(02)02621-2

8 Reddy BV, Lee J, Cunningham PL. Giant uterine leiomyoma with air-fluid levels. J Am Coll Surg. 2004;198(05):844-845. Doi: 10.1016/j.jamcollsurg.2003.11.027

9 Pérez M, Ramón JM. Large abdominal mass due to a giant uterine leiomyoma. Mayo Clin Proc. 2006;81(11):1415. Doi: 10.4065/ 81.11.1415

10 Nappi L, Matteo M, Giardina S, Rosenberg P, Indraccolo U, Greco P. Management of uterine giant myoma. Arch Gynecol Obstet. 2008; 278(01):61-63. Doi: 10.1007/s00404-007-0523-1
11 Amber I, Kennedy G, Martinez H, Pearson JM, Jimenez E. A leiomyoma in a cachectic woman presenting as a giant abdominal mass. J Radiol Case Rep. 2009;3(10):23-29. Doi: 10.3941/jrcr.v3i10.324

12 Semczuk A, Skorupski P, Olcha P, Skomra D, Rechberger T, Gogacz M. Giant uterine leiomyomas causing bilateral hydronephrosis coexisting with endometrial cancer in polyp: a case study. Eur J Gynaecol Oncol. 2009;30(03):344-346

13 Săvulescu F, Iordache I, Albița O, Hristea R, Dumitru C, Iordache A, et al. Giant uterine leiomyoma. Chirurgia (Bucur). 2011;106(05):665-668

14 Aydin C, Eriş S, Yalçin Y, Sen Selim H. A giant cystic leiomyoma mimicking an ovarian malignancy. Int J Surg Case Rep. 2013;4 (11):1010-1012. Doi: 10.1016/j.ijscr.2013.08.018

15 Máté S, Szatmári E, Sipos N, Széll J, Szánthó A, Rigó J Jr. [Giant uterine leiomyoma causing acute symptoms]. Orv Hetil. 2013;154 (10):387-390. Doi: 10.1556/oh.2013.29563

16 Orazulike NC, Green KI, Uzoigwe SA. Giant uterine fibroids: consequences of delay in presentation. Eur J Obstet Gynecol Reprod Biol. 2015;194:251-252. Doi: 10.1016/j.ejogrb.2015.06.034

17 Ezugwu EC, Iyoke CA, Ezugwu FO, Ugwu G. Successful pregnancy following myomectomy for giant uterine fibroid in an infertile woman. J Reprod Infertil. 2014;15(04):233-236

18 Moris D, Vernadakis S. Giant uterine leiomyoma mimicking pregnancy. Mayo Clin Proc. 2014;89(06):e53-e54. Doi: 10.1016/j.mayocp.2013.06.029

19 Sonoo T, Tokunaga K, Fukuda T, Nakamura K. Cardiac arrest induced by a giant uterine leiomyoma. BMJ Case Rep. 2015; 2015:bcr2015213370. Doi: 10.1136/bcr-2015-213370

20 Lim PT, Tan CH, Chia HL, Phoon J. Management of a giant uterine leiomyoma. BMJ Case Rep. 2018;2018:bcr2017224052. Doi: 10.1136/bcr-2017-224052

21 Kogan EA, Zharkov NV, Askolskaya SI. Popov, Krot MA, Demura TA. [Growth mechanisms and morphological structural features of large uterine leiomyoma]. Arkh Patol. 2018;80(05):16-22. Doi: 10.17116/patol20188005116

22 Moroni RM, Vieira CS, Ferriani RA, Reis RM, Nogueira AA, Brito LG. Presentation and treatment of uterine leiomyoma in adolescence: a systematic review. BMC Womens Health. 2015;15:4. Doi: 10.1186/s12905-015-0162-9 